\title{
CORRESPONDENCE
}

\section{EXTRA-CONJUNCTIVAL IMPLANTS}

\section{To the Editorial Committee of the British Journal of Ophthalmology}

SIRs-The technique described by Nairac (1954) is ingenious, but founded upon a doubtful principle. Most authorities on orbital implants (movable ocular prostheses) agree that, to stand a chance of being retained for more than 5 years, an implant must be completely enclosed in both Tenon's capsule and the conjunctiva (Choyce, 1954; RoperHall, 1954). The union described by Nairac between tantalum and naked muscle, not covered by Tenon's capsule and conjunctiva, is very likely to fail after 1 to 2 years at the most.

The author makes no reference to numbers of cases or to the length of time which has elapsed since operation. If he is able to indicate that a substantial proportion of his implants are still in situ 5 years after the operation, I shall be the first to congratulate him, but I do not believe he will find himself able to demonstrate such a degree of success.

In my opinion, by adopting this technique, he has rendered his patients a disservice, because the opportunity has been missed of inserting a completely buried implant at the time of enucleation.

Yours faithfully,

D. P. СHоYCe.

33, Wimpole Street,

LONDON, W.1.

July 16, 1954.

\section{REFERENCES}

CHOYCE, D. P. (1952). British Journal of Ophthalmology, 36, 123.

NAIRAC, M. L. (1954). Iibid., 38, 378.

Roper-HALL, M. J. (1954). Trans. ophthal. Soc. U.K., 74. (In the press).

\section{NOTES}

\section{BRITISH ORTHOPTIC JOURNAL}

THE latest issue of the British Orthoptic Journal, which appeared in June this year, is wellarranged and illustrated, and betrays evidence of the sub-editor's work in pruning and styling. The science of orthoptics is seen to be making progress in Switzerland, Belgium, Holland, and Australia, as well as in this country, and it is plain that the orthoptists interest themselves in a wide range of allied subjects outside their specialized clinics. Since 1939, when it first came out, this journal has been limited to one number each year, but the newly-constituted editorial committee under Miss Joyce Mein's leadership hopes to produce it in future at six-monthly intervals. Despite rising costs in recent years, the annual subscription has remained at ten shillings, and the British Orthoptic Journal committee hopes that the policy of supplying two issues a year will not entail any increase in subscription. This hope may perhaps be translated into certainty if the list of subscribers can be augmented. Nearly all practising orthoptists already subscribe, but hitherto the support from ophthalmologists has been disappointingly small. Medically-qualified people have often supposed that the Orthoptic Journal consists entirely of papers dealing with technical aspects of orthoptic work; and admittedly it is impossible for most ophthalmologists to become familiar with all the routine methods of investigation and treatment 